\title{
Polyester/paper composites: study of manufac- turing techniques for product development
}

Jussara Smidt Porto ${ }^{1}$, Clarissa Coussirat Angrizani ${ }^{2}$, Eliana Paula Calegari ${ }^{3}$, Sandro Campos Amico ${ }^{2}$, Lauren da Cunha Duarte ${ }^{1}$

\author{
${ }^{1}$ Programa de Pós-graduação em Design, PGDesign /UFRGS, Oswaldo Aranha Avenue, 99, CEP: 90035-190, Porto Ale- \\ gre, Rio Grande do Sul, Brasil. \\ ${ }^{2}$ Programa de Pós-Graduação em Engenharia de Minas, Metalúrgica e de Materiais, PPGE3M/UFRGS, Bento Gonçalves \\ Avenue, 9500, CEP: 91501-970, Porto Alegre, Rio Grande do Sul, Brasil. \\ ${ }^{3}$ Instituto Federal de Rondônia campus Porto Velho zona norte, Tiradentes Avenue, 3009, CEP: 76821-001, Porto Velho, \\ Rondônia, Brasil. \\ e-mail: jussara.porto@ufrgs.br, cangrizani@gmail.com, elianapaulac@gmail.com,amico@ufrgs.br, lauren.duarte@ufrgs.br
}

\begin{abstract}
Composite materials using vegetal fibers and industrial waste are being applied in different areas and structures, requiring, more and more, researches that highlight their characteristics. In this context, the study of manufacturing techniques becomes increasingly necessary in order to use the appropriate tools and obtain the best conditions of the materials. Thus, this article demonstrates the behavior of the materials, which used the polyester resin with ground paper residue to generate the two composites studied in this paper, Polyester/smaller paper (PO/ PME) and Polyester/large paper (PO/PMA). These two materials were molded by hot compression and subjected to manufacturing processes. Joinery equipment were chosen for the experimentation of cutting, drilling, screw insertion and sanding to analyze the performance of these composite materials. As a general result, it can be observed that the composites maintained their physical integrity, because the particles of the load remained well anchored in the matrix in the two composite materials tested, giving the finish an aspect without damages, cracks or imperfections after the operations. Therefore, it is concluded that the materials created can be submitted to the manufacturing techniques evaluated in this article, reinforcing previous studies that suggest its use in the development of products such as furniture, table tops, decorative objects and others. Thus, this study contributes to Designer has knowledge of the potential of the material and make the best use of it.
\end{abstract}

Keywords: Composite, manufacturing techniques, cutting, finish.

\section{INTRODUCTION}

For the development of new materials, it is considered that the knowledge of their behavior, their properties and the manufacturing techniques are fundamental to identify and use them. The analysis of these aspects is essential so that designers and professionals of the area can indicate them as alternatives to traditional products. Also for the composites, GUIMARÃES et al. [1] commented that, with the increasing use of these materials in the most varied types of structures, it is necessary to know the possibilities of processing after the molding to make feasible a better applicability.

In relation to the composite materials, CANDIDO [2] affirms that it is advantageous to produce composites using industrial waste as a load from a technological and social point of view, since they can help reduce the volume of landfill, reduce the risk of soil contamination and urban landscape degradation, and promote new ways of using this waste. The industrial sector is responsible for generating a large amount of this waste, and in the printing workshop, for example, 63\% of the material discarded from the printing process is not reused (RECICLAGEM DE PAPEL [3]).

In this work the focus is on the performance of composites with waste paper originated from graphical processes and polyester resin in the maximum proportions of paper saturation in manufacturing techniques that use applied tools predominantly in the production of wooden furniture.

According to DURÃO et al. [4], the inefficacy of a material against these techniques can cause part rejection or shortening of its life. LOPRESTO et al. [5] and KARATAS and GOKKAYA [6] point out that the difficulty of machining is due to its anisotropic appearance, the lack of homogeneity in its microstructure and the abrasiveness of its constituents, 
the latter is specifically found in reinforced composites by fibers. The authors also point out that manufacturing techniques such as turning, drilling and milling are increasingly required for the manufacture of composites and can be successfully applied if the correct tools are used and the proper machining conditions are achieved.

FERREIRA [7] also draws attention to delamination defects because imperfections resulting from drilling processes are very common. For ALVES et al. [8], several factors can influence the general quality of the processed components such as type of material to be machined, speed of operation of the equipment, type of chip generated, grit size of abrasive, among others. They also emphasize that in order to obtain a quality product, a suitable combination of these factors is necessary, thus avoiding delamination, fiber pulling, fiber / matrix adhesion loss, and heat damage during processing.

Although there are studies in the literature of manufacturing techniques in composites, no reports were found on composites reinforced with waste paper. In this way, the objective of this work is to verify the behavior and the finishing of the composites developed with waste paper/ polyester from experiments with manufacturing techniques directed to the product design. Thus, this study may contribute to the application of new composite materials containing waste paper of any nature.

\section{MATERIALS AND METHODS}

\subsection{Materials}

For the development of the composites, the unsaturated polyester resin orthophthalic Raicholp and Butanox M-50 (1.3\% v/ $\mathrm{v})$ initiator and, as load, two types of waste paper from different finishing equipment of the printing manufacturing process, such as the Mini Max Drilling Machine and the Eurobind Colander of the brand Heidelberg. The original paper is the offset from International Paper, grammage $75 \mathrm{~g} / \mathrm{m}^{2}$ and a moisture content of $6 \%$, in the dimensions of $\approx 2 \mathrm{~mm}$ for the smaller paper (PME) and $5 \mathrm{~mm}$ for the larger paper (PMA).

\subsection{Methods}

The methodology adopted in this work was divided into two stages: firstly the composite material was developed and the experiments were done with fabrication techniques. Polyester / smaller paper (PO/PME) and polyester/ larger paper (PO/ PMA) plates in the dimensions of $27 \times 17 \times 0.35 \mathrm{~cm} 3$ with $80 \%$ mass fraction of PME or PMA were made. For this purpose, the collection and selection of waste paper from UFRGS 'Printing was initially performed. The paper chips were taken to the oven with air circulation brand Deleo - A5 AFD for $2 \mathrm{~h}$ at $60^{\circ} \mathrm{C}$ for extraction of moisture. The materials were weighed, and then the polyester resin was manually mixed with the paper residue, and after the residues were completely wrapped by the resin the initiator was added. Subsequently, the material was placed into the internal mold cavity and left to the Marconi MA 098/A hydraulic press for hot compression molding $\left(3\right.$ bar and $80^{\circ} \mathrm{C}$ ) for $75 \mathrm{~min}$, which resulted in curing the composite. Afterwards, the composites were extracted from the mold and led to the oven for $4 \mathrm{~h}$ at $60{ }^{\circ} \mathrm{C}$ for post cure of the resin.

In this work, when manufacturing techniques are mentioned, the authors refer to operations performed on the composite after its post cure. The equipment used in the experimentation of these processes were:

- Saw brand Dexter, with a $35 \mathrm{~cm}$ long steel blade, with 12 teeth per inch.

- Tape saw of the brand Tekna model SF 400T, with blade length of $295 \mathrm{~cm}$, speed of $10 \mathrm{~m} / \mathrm{s}$.

- Sliding table saw brand Maksiwa model ESQ-3000 I, with engine of $5 \mathrm{CV}$ and $3510 \mathrm{rpm}$ speed, using a disk of the brand Freud model LU3A-0200 with external diameter of $250 \mathrm{~mm}, 30 \mathrm{~mm}$ hole and 80 alternating teeth E/D $38^{\circ}$.

- Milling machine of the brand WMW model FUW, with cutting speed of $220 \mathrm{~mm} / \mathrm{min}$ and rotation of $355 \mathrm{rpm}$; using a high speed steel mills with $10 \mathrm{~mm}$ diameter.

- Drilling machine/screwdriver brand DeWalt model DCD700, with battery $12 \mathrm{~V}$, with standard twist drill $4 \mathrm{~mm}$ in diameter. To perform the holes, it was used head Phillips screws wood screws with $3.5 \mathrm{~mm}$ diameter. In addition, a $10 \mathrm{~mm}$ milling cutter was used in the drilling machine/ screwdriver of brand Forstner.

- Disc and tape sander brand Maksiwa with a speed of $1700 \mathrm{rpm}$. The tape sandpaper used was of brand Indasa model $\mathrm{PH}$ of grain 60 .

The milling operation was carried out at the Machining Laboratory of the Mechanical Engineering course at UFRGS. Already the cutting and finishing operations with the tools applied in the production of wooden furniture (cutting, drilling, sanding and bonding of screws) were carried out at the Confraria da Madeira Company in Porto Alegre. 


\subsubsection{Experimentation with manufacturing techniques}

The methodology adopted for the analysis of the experiments of the manufacturing techniques was based on the investigation of tactile and visual aspects according to the literature. Table 1 presents the processes and aspects evaluated.

Table 1: List of manufacturing techniques and aspects analyzed.

\begin{tabular}{|c|c|c|c|}
\hline Cutting & Drilling & Screw fastening & Sanding \\
\hline $\begin{array}{l}\text { - Ease of cutting; } \\
\text { - Behavior of material in relation to } \\
\text { the equipment; } \\
\text { - Bonding reinforcement / matrix; } \\
\text { - Note of voids (in surface and inter- } \\
\text { nally); } \\
\text { - Burrs; } \\
\text { - Chips; } \\
\text { - Cracks; } \\
\text { - Displacement fiber / matrix; } \\
\text { - Removal of fibers; } \\
\text { - Chemical modifications due to the } \\
\text { heating of the material. }\end{array}$ & $\begin{array}{l}\text { - Delamination; } \\
\text { - Geometric defects; } \\
\text { - Chemical modifications } \\
\text { due to the heating of the } \\
\text { material; } \\
\text { - Behavior of the material } \\
\text { in relation to equipment. }\end{array}$ & $\begin{array}{l}\text { - Integrity of the com- } \\
\text { posite during and after } \\
\text { the screw fastening; } \\
\text { - Generation of } \\
\text { burrs; } \\
\text { - Generation of } \\
\text { chips; } \\
\text { - Generation of } \\
\text { cracks. }\end{array}$ & $\begin{array}{l}\text { - Preparation of surface; } \\
\text { - Quality of the surface, } \\
\text { smooth/rough, opaque/ } \\
\text { gloss. }\end{array}$ \\
\hline
\end{tabular}

OLIVEIRA et al. [9] and FERREIRA [7] observed in their studies aspects such as ease of cutting, material behavior in relation to equipment operation, reinforcement / matrix adhesion, appearance of voids (both on the surface and internally), delamination, cracking, burrs, fiber/matrix displacement, fiber pullout, thermal damage (relative to the heat generated during processing) and sanding finish.

In relation to drilling, the recommendation of LACHAUD et al. [10] that suggests the observation of delamination (in the entrance and the exit of the tool in the part), and of geometric and thermal defects (increase of the temperature of the material due to the friction between the fibers and also of the tool with the wall of the hole) was followed.

The holes were observed with a magnifying lens for analysis of the occurrence defects in the composites. For the placement of the screws, it was decided to use standard twist drill, low feed rate and high cutting speed (rotation) to reduce the risk of delamination, as recommended by MELENTIEV et al. [11].

Sanding is an operation that results in the removal of material from a part to obtain a shape or a certain surface, this process is made with sandpapers which are composed of abrasive papers as mentioned by ALVES et al. [8]. According to VARASQUIM [12] the sandpaper is used to adapt the material to the geometrical limits of the piece and to level and refine the surface. Dry sanding was used in this study to simulate finishing after a cutting operation, and thus to prepare the material for the use of varnishes, paints, sealants, coatings, etc.

\section{RESULTS AND DISCUSSIONS}

The studied composites are shown in Figure 1, it is noted that they have a suitable quality for the development of products for applications that do not require high mechanical performance, focusing on the visual aspect sustainable, since it has paper chips discarded from UFRGS 'Printing. Due to the translucency of the polyester, paper chips can be observed in both the smaller paper composite (Figure 1b) and the larger paper composite (Figure 1a), resulting in a heterogeneous texture. Visually, the appearance associated to granite is still outstanding, mainly in the composite PO / PME (Figure 1b). 

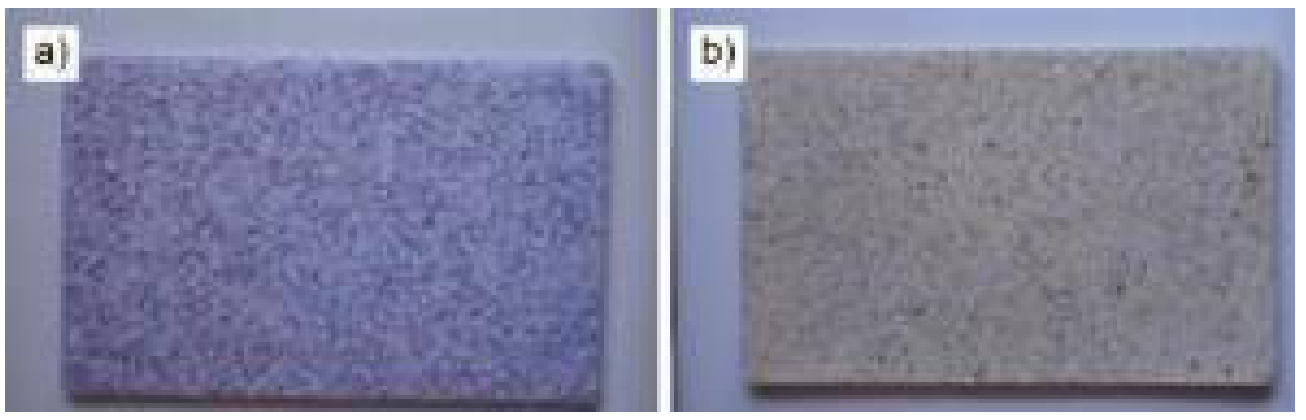

Figure 1: Visual aspect of the studied composites: PO/PMA (a) and PO/PME (b).

\subsection{Saw cutting}

There was no difficulty in using the saw in both samples (PO/PMA and PO/PME). The force employed in the execution of this operation was moderate, which is important since the operation is manual, being similar to the effort used to cut the wood. And got a reasonable finish with this hand tool (Figures 2-3), since it did not generate a rectilinear cut, which is common because it is a hand tool.
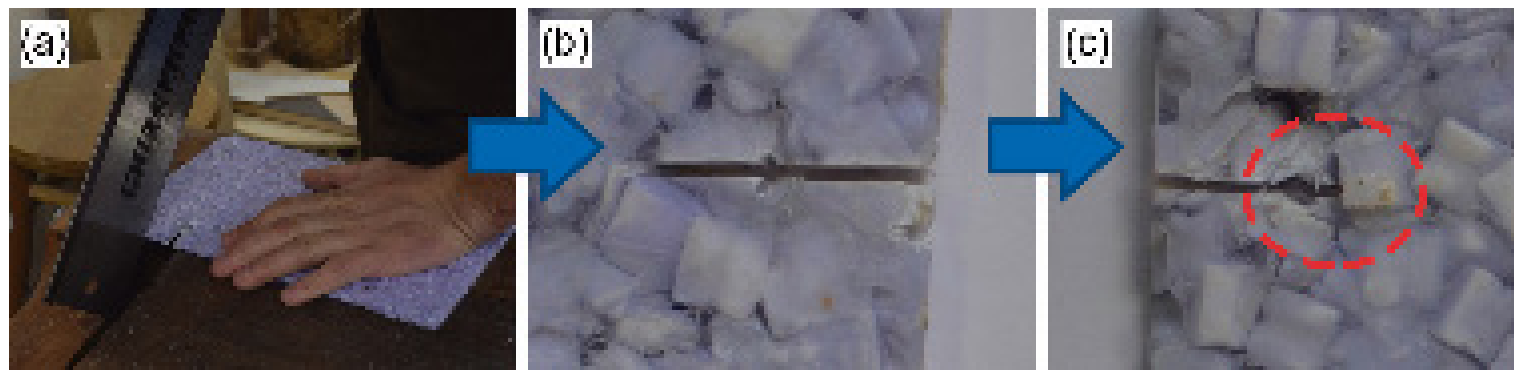

Figure 2: Cutting with saw: cutting operation in the PO/PMA sample (a), upper surface (b) and lower surface (c) of the cut sample.
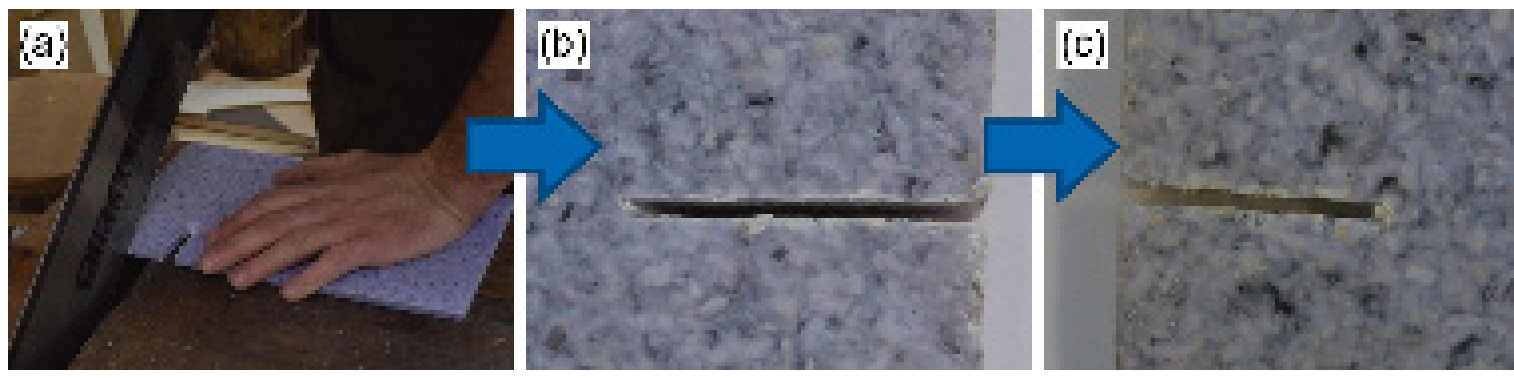

Figure 3: Cutting with saw: cutting operation in the PO/PME sample (a), upper surface (b) and lower surface (c) of the cut sample.

For the PO/PME composite, the integrity of the material was maintained during and after cut (Figure 3a-3c), and no cracks and chips were observed. Already for the PO / PMA composite, chips occurred on the lower surface of the cut, which, with a slight pressure, were easily detached from the material, resulting in imperfections on its surface. This is probably due to the lower adhesion of the PMA to the polyester, as can be seen by the apparent surface bubbles in the PO / PMA composite (Figure 2a-2c).

In the PO / PMA composite, some burrs appeared due to on the chipping in the cut region leaving waste paper visible (Figure 2b-2c). The same did not occur in the PO / PME composite although the two composites have a mass fraction of $80 \%$ in paper, probably because this composite has smaller particles that facilitate the wettability of the paper by the polyester resin, improving adhesion and reducing voids in the material.

Thus, although the saw cutting resulted in a finishing "coarse" in both samples and is not recommended for work that requires cutting and finishing accurate, it can be concluded by visual analysis that the PO/PME composite presented a better finish in this operation. 


\subsection{Tape saw cutting}

Unlike sawing, this operation is performed with a electric machine. The cutting speed used was $10 \mathrm{~m} / \mathrm{s}$, similar to the speed of cutting for wood operations with the same thickness of the analyzed material. Productivity similar to wood was observed, and there was no vibration of the cutting blade, thus appearing ease in cutting.

One can observe in the cut with tape saw a good integrity of the PO/ PMA and PO/PME composites during and after cutting, there being no cracks in the material or generation of burrs and chips (Figures $4 a-4 b$ and $5 a-5 b$, respectively). The materials were cut with facility and the cut surface wall did not showed irregularities and change of color, being observed only grooves (vertical marks) of the cut in the samples.
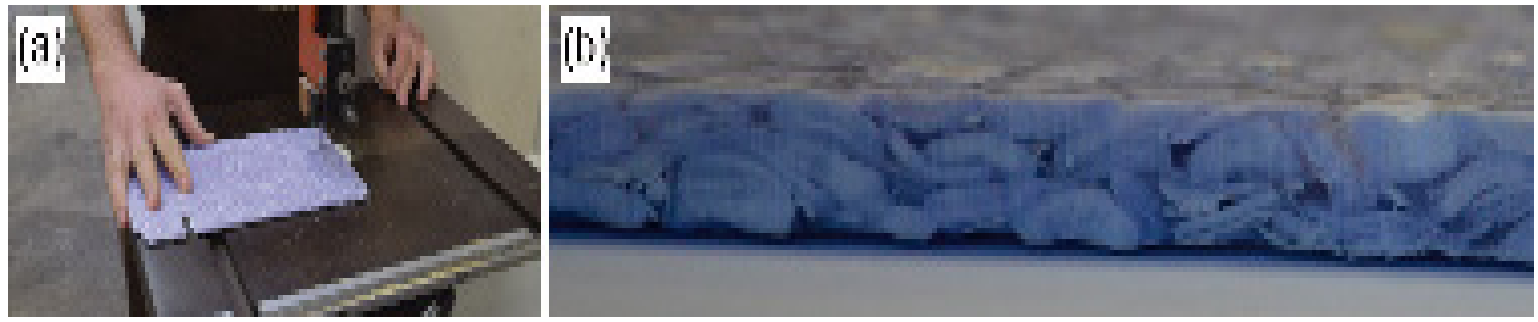

Figure 4: Tape saw cutting of the PO/PMA sample: cutting operation (a) and cut sample surface (b).
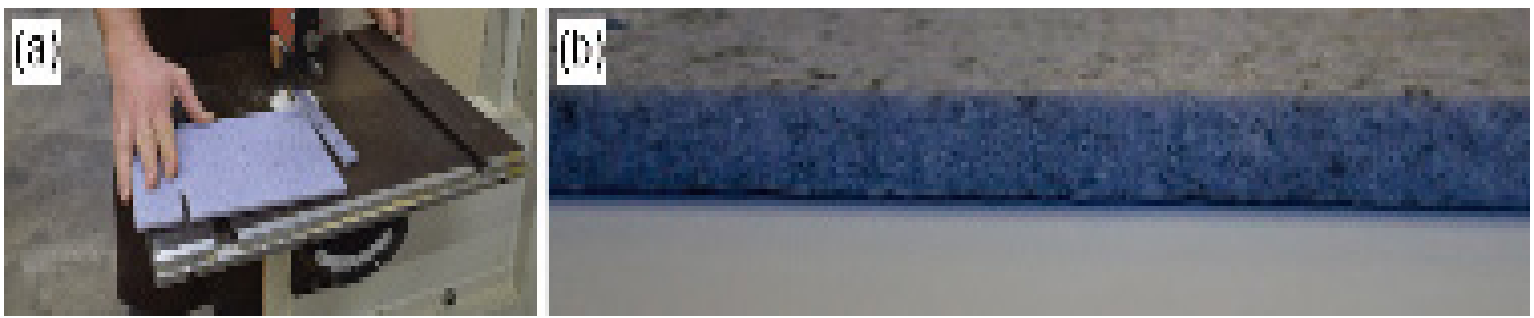

Figure 5: Tape saw cutting of the PO/PME sample: cutting operation (a) and cut sample surface (b).

\subsection{Sliding table saw cutting}

The PO/PMA and PO/PME composite cut with the sliding table saw (Figures $6 \mathrm{a}-6 \mathrm{~b}$ and $7 \mathrm{a}-7 \mathrm{~b}$, respectively) presented a better finish compared to the other (saw and tape saw) possibly due to higher cutting speed, and the the power of the equipment and the speed of rotation of the disc. It was also observed that the faces of the cuts were more uniform in relation to the previous procedures. Thus for a more sophisticated manufacturing process, there is a tendency to improve the quality of the part, with less damage due to the manufacturing and reducing the need for rework.
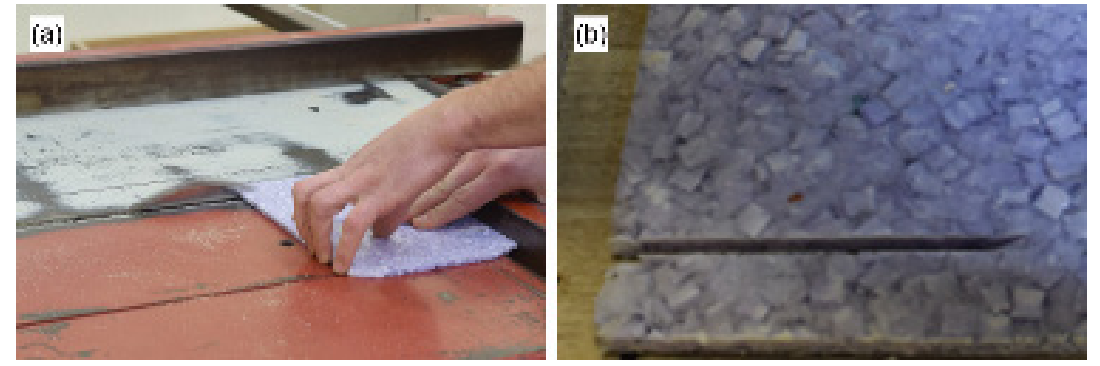

Figure 6: Sliding table saw cutting of the PO/PMA sample: cutting operation (a) and cut sample surface (b).
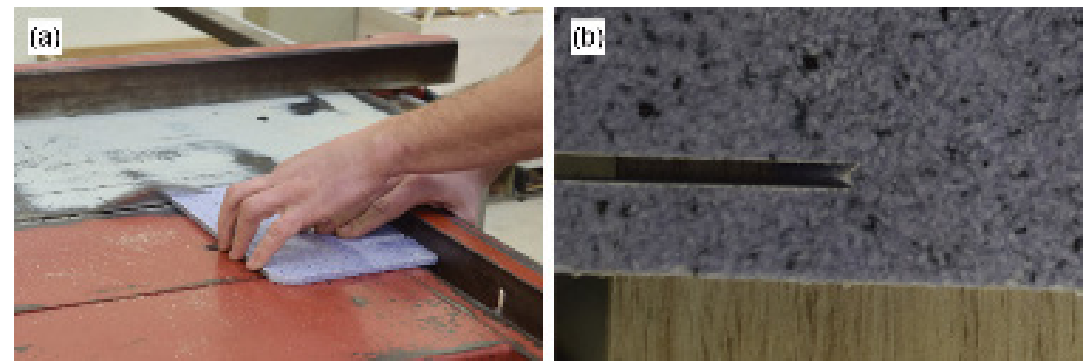

Figure 7: Sliding table saw cutting of the PO/PME sample: cutting operation (a) and cut sample surface (b). 


\subsection{Cutting with conventional milling machine}

According to RITTER and FARIAS [13], during the machining process, aspects such as pressure of the tool against the part, friction of the surface of incidence of the tool with the part, heat generated in the cutting process and vibration of the tool can be responsible for changes in material properties, affecting the quality of the cutting surface of the parts. On the other hand, OLIVEIRA et al. [9] studied the machinability of epoxy/ aluminum powder composite materials and verified that a more sophisticated machining process, such as computerized numerical controller (CNC) milling, can reduce the damages caused by processing.

The results with machining showed more imperfections in the PO/ PMA material, which also showed a change in color (more yellowish tonality) probably due to the pressure of the tool against the part and the temperature obtained during the process, demonstrating chemical changes in the surface of the cut. The burrs resulting from the cut were well visible on the upper and lower surfaces of the cutting, resulting in imperfections that can compromise performance and finish of the part, and would require sanding operations to thin the material. These details can be seen in Figure $8 \mathrm{a}-8 \mathrm{~b}$.

In relation to the PO/PME composite (Figure 9a-9b), the change in shade of the material was no longer so evident and the formation of burrs was much less pronounced than in the PO/PMA. This characteristic is probably due to the size of the paper residue inserted in the composite, which makes the PO/PME more homogeneous allowing a better machining.

The machining operation did not result in cracking or separation of waste paper into the material. But when comparing the two materials, a better finish on the cutting surface in the PO/PME, demonstrating a straight cut, with few burrs, which was not the case for the PO/PMA which would require a larger sanding on the machined surface.
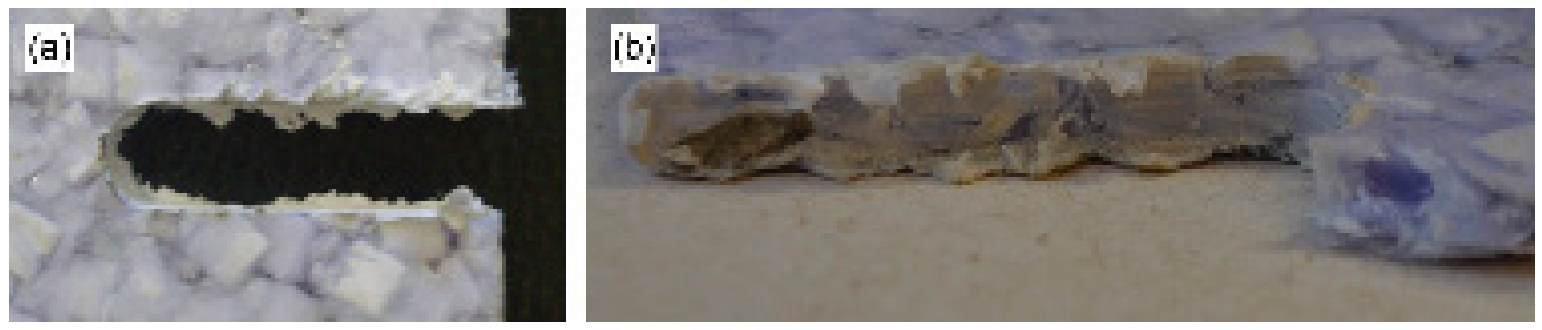

Figure 8: Cutting with machining in the PO/PMA sample: cutting operation (a) and appearance of cutting surface (b).
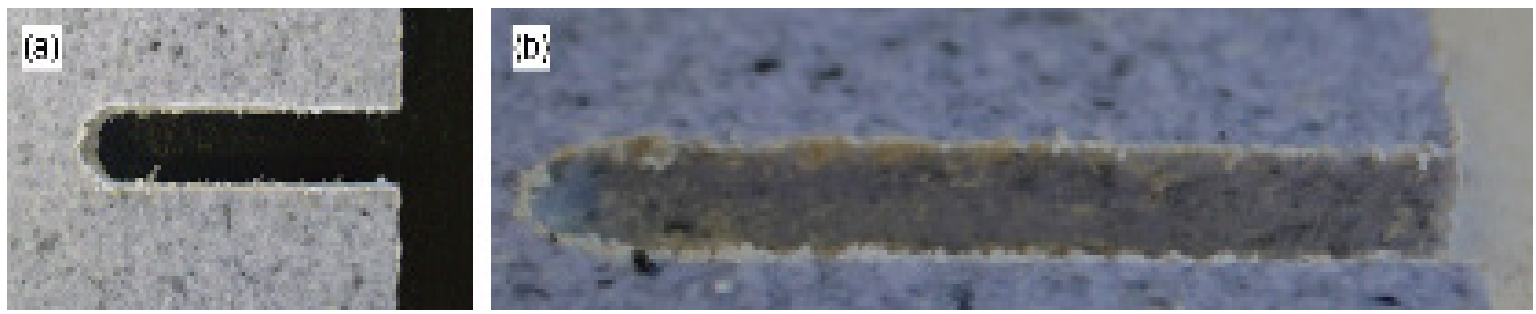

Figure 9: Cutting with machining in the PO/PME sample: cutting operation (a) and appearance of cutting surface (b).

According to RITTER and FARIAS [13], machining is used due to the freedom in geometries that can be obtained with high dimensional accuracy and good surface finish, without promoting significant changes in the properties of material, as was observed in this work for the PO/PME. But those authors point out that, despite a number of advantages, the machining speed of production is low. The choice of this process for the PO/PME, which demonstrated greater adequacy, will depend on factors such as time available, product complexity, amount of production and cost generated.

Unlike the reports in the literature for fibrous composites, where LOPRESTO et al. [5] mentions that fiber orientation may cause difficulty in the performance of the PO/PME and PO/PMA samples in the three types of cutting was benefited by the fact that they were particulate loads of random orientation, neither interfering with the handling nor causing an irregular appearance, generating a better finish than fiber reinforced composites. Even for the PO/PMA there was no influence, although this material larger particles.

\subsection{Perforation and Screw Testing}

Drilling, a dominant composite operation, is particularly difficult because the material can chip or even split into separate layers (delamination) at the entrance and exit of the tool from the hole, this can affect the structural integrity and long-term 
reliability of the composite (XU et al. [14]).

The drilling process depends on parameters such as geometry of the drills and the way the edges work inside the workpiece. According to GUIMARÃES et al. [1], the mechanical action exerted by the drill plastically deforms the zone around the hole surface, with small irregularities that increase the probability of a cracking initiation due to the increase of stresses located inside the hole.

According to SANKAR et al. [15], depending on the geometry of the tip of the drill bit, the efficiency of screw fixation can be reduced and the quality of the hole in the composite can be compromised. However, as in the works of EBERHARDT et al. [16] and EL-SONBATY et al. [17], it can be verified that the drill geometry (used to make a pre-drill to minimize the effect of the drill edges) used for the screw fixation was compatible with the study material and did not compromise its surface .

In Figures 10a-10c and 11a-11c it is observed that the surface of the materials (PO/PMA and PO/PME, respectively) remained unchanged. There was no delamination at the entrance of the hole, no geometric defects, or some damage related to temperature, at the entrance and exit of the hole. The friction of the tool with the constituents of the composite did not cause changes in the material that could render it unusable for fixing a screw. It was also observed that there was no paper extraction that could cause undesirable consequences for the quality of the workpiece surface even for the PO/PMA that in the cutting operation with the milling machine had shown apparent changes (burrs) in the edges of the machined surfaces.
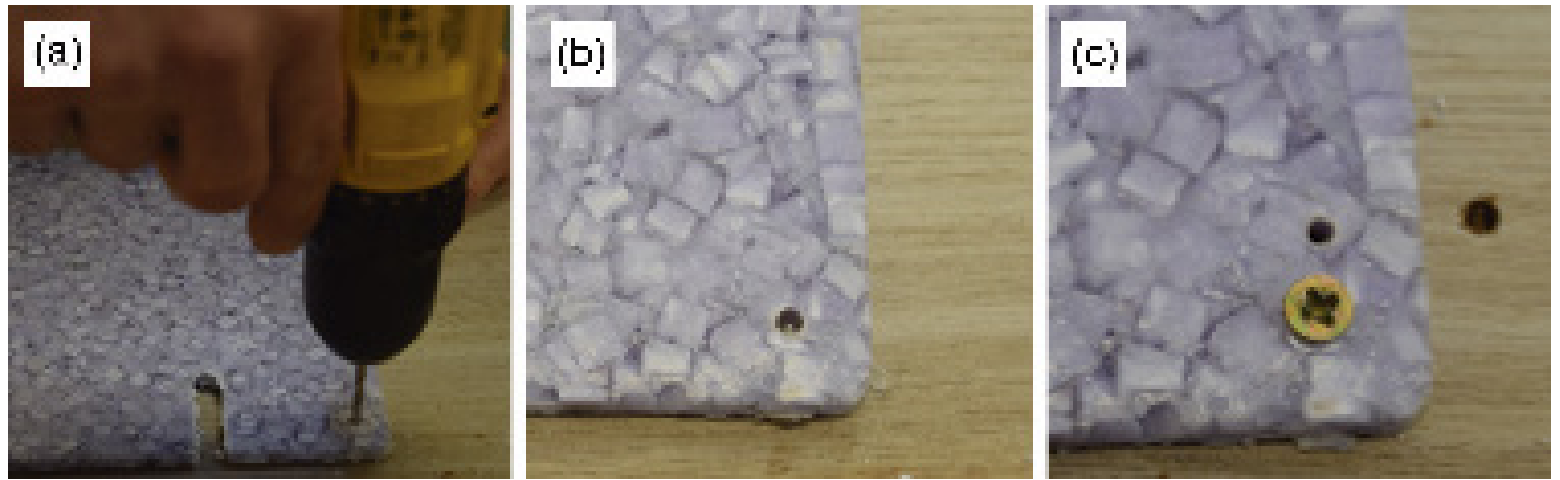

Figure 10: Cutting with machining of the PO/PMA composite: hole with drill (a), appearance of hole (b) and fixed screw in the PO/PMA composite (c).
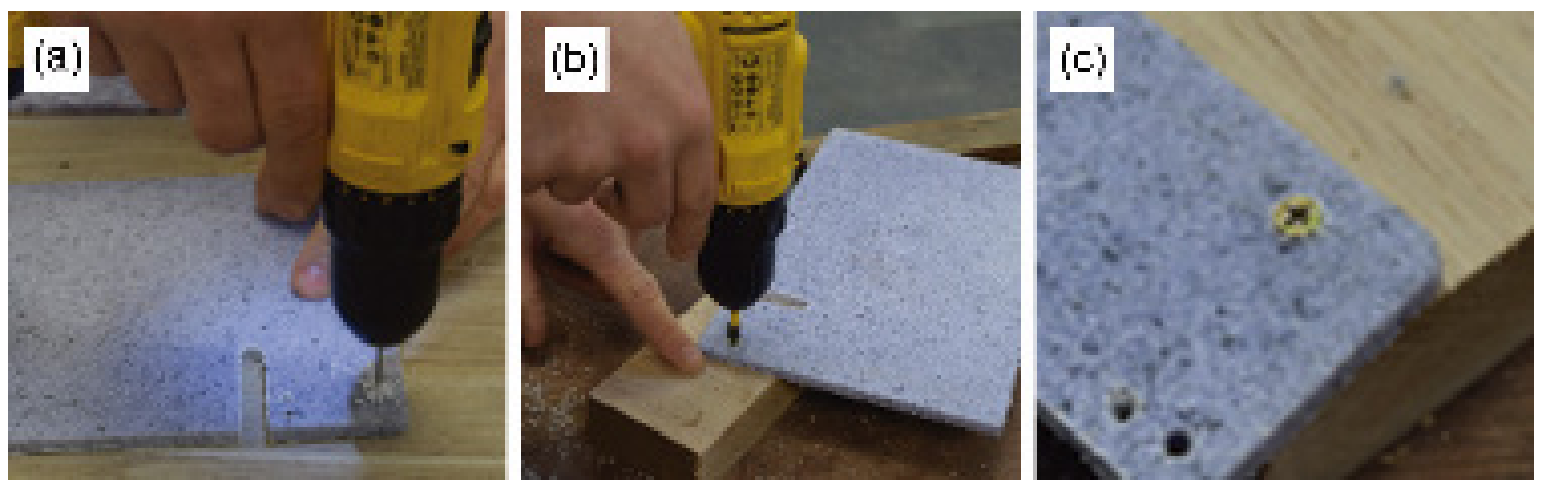

Figure 11: Cutting with machining of the PO/PME composite: hole with drill (a), appearance of hole (b) and fixed screw in the PO/PME composite (c).

According to CAPELLO [18] the holes can be realized without support, with shock absorber and with support under the part, however the use of it improves significantly the quality of the hole, reducing the bulging of the composite caused by the pressure of the drill bit on the part. In this work, it was verified that the two materials have performed satisfactorily in this procedure even without the use of support to improve the quality of the hole.

\subsection{Sanding}

The materials produced (PO/PME and PO/PMA) went through the process of sanding at the edges. In general, we obtained final standards of suitable finishes to receive cover products such as sealants, paints or varnishes. The PO/PMA material 
was subjected to sanding procedure with sander for sanding the edges of the plates (Figure 12) and did not presente difficulties in carrying out the procedure. For this experiment, according to Figures 12a and 13a, an angle of contact with the sandpaper of approximately $45^{\circ}$ was maintained to reduce the removal of the material.

As the pressure of the composite was increased on the sandpaper, increased the material removal rate, but it was not checked paper pullout and imperfections in the rubbed edges of the composite (Figures $12 \mathrm{~b}$ and 13b). Even for the PO/ PMA, which had a larger waste paper area than the PO/PME, the sanded surface remained intact, showing good appearance, as shown in Figures $12 \mathrm{~b}$ and 13b. The two materials did not change in the staining, indicating a non-significant increase in the local sanding temperature, indicating that an adequate speed was used in the equipment.
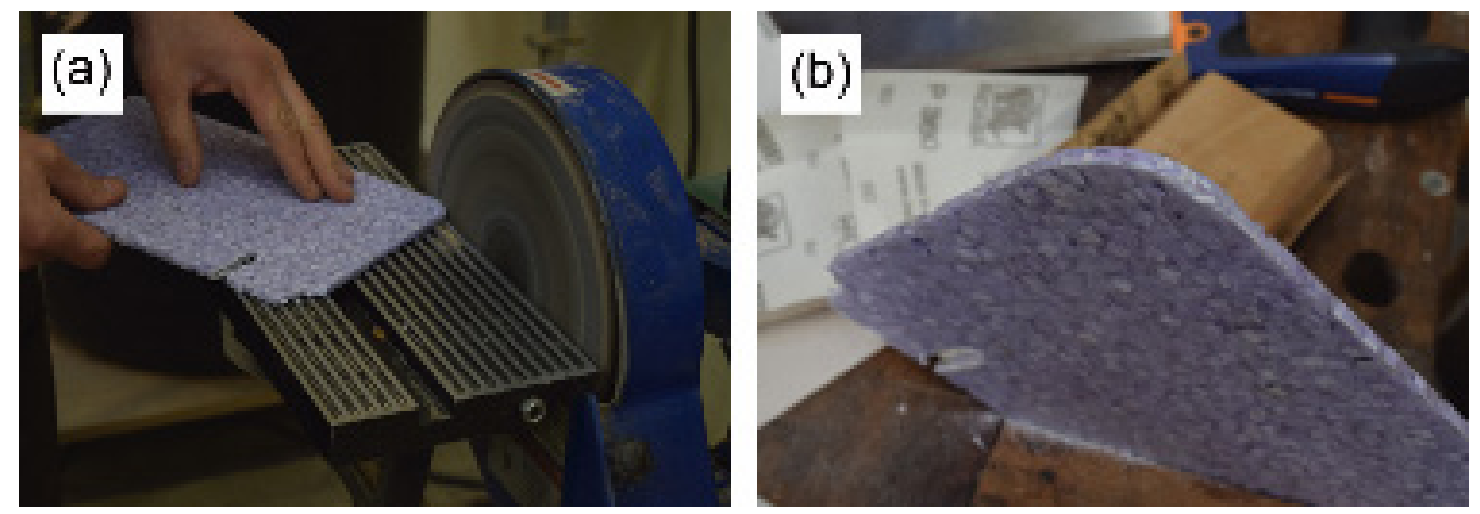

Figure 12: Sanding process: sanding of the PO/PMA sample (a) and apparent edges (b).
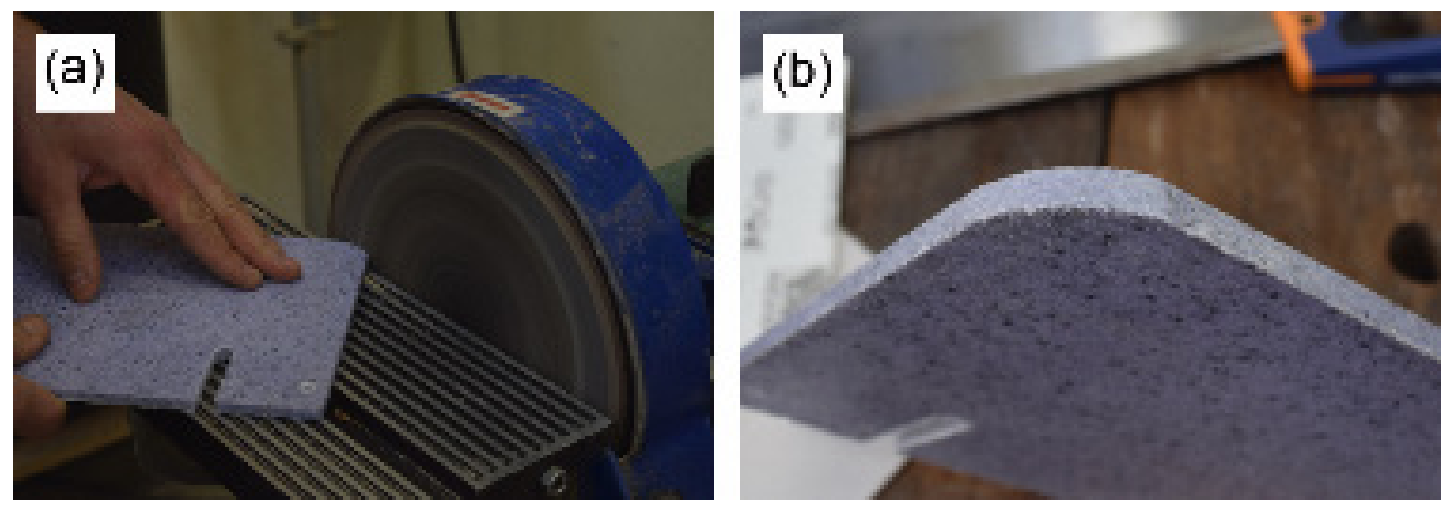

Figure 13: Sanding process: sanding of the PO/PME sample (a) and apparent edges (b).

\section{CONCLUSION}

The manufacturing techniques are used after the molding of composite materials to assign the final shape to the product. In this study, the experiments with cutting, drilling and sanding processes were important to identify the possibility of using them in this new material, in order to enable future applications in products.

In cutting operations that rely more heavily on the operator's ability, the result was lower. It was observed that, among the processes and methodologies adopted, the performance of the material in the sliding table saw machine presented a better accomplishment. In general, the PO/PME composite showed a superior result than the PO/PMA, probably due to the lower void content caused by the reduced paper size, which may result in less discontinuities during the material removal operation.

As for the drilling and sanding operations, both presented satisfactory results. In relation to the drilling, the particles of the load remained well anchored in the matrix in the two materials tested, which generated few pullouts and favored the surface quality of the holes. And dry sanding did not cause damage to materials.

Therefore, in general, it can be concluded that composite materials obtained with waste paper presented indications that can be submitted to the cutting, drilling and sanding processes, with limited damages. Thus, this study contributes to the Designer has knowledge of the material potential and make the best use of it for the development of products such as furniture, table tops, decorative objects among others, obtaining quality in the finish. 


\section{ACKNOWLEDGEMENTS}

The authors thank the mechanical engineering department from UFRGS for the use of the milling machine.

\section{BIBLIOGRAPHY}

[1] GUIMARÃES, J.L., BAPTISTA, A.M., ALVES, J.L., et. al., "Desenvolvimento de ferramentas de corte para a furação de laminados compósitos", In: II Jornada Luso-Brasileira de Ensino e Tecnologia em Engenharia - JLBE, Instituto Politécnico do Porto, pp.1-8, Porto, Portugal, 2009.

[2] CANDIDO, V.S., "Caracterização e propriedades de compósitos poliméricos reforçados com fibras de bagaço de cana-de-açúcar”, Tese de Doutorado, Instituto Militar de Engenharia, Rio de Janeiro, Brasil, 2014.

[3] RECICLAGEM DE PAPEL. http://www.portalresiduossolidos.com/reciclagem-de-papel-2/, acessado em junho de 2019.

[4] DURÃO, L.M.P., GONÇALVES, D.J.S., TAVARES, J.M.R.S., et al., "Dano na furação de placas carbono/epóxido", Revista Iberoamericana de Ingeniería Mecánica, v. 17, n. 1, pp. 27-38, 2013.

[5] LOPRESTO, V., CAGGiAnO, A., TETI, R., "High Performance Cutting of Fibre Reinforced Plastic Composite Materials", Procedia CIRP, v. 46, pp. $71-82,2016$.

[6] KARATAS, M.A., GOKKAYA, H., "A review on machinability of carbon fiber reinforced polymer (CFRP) and glass fiber reinforced polymer (GFRP) composite materials”, Defence Technology, v. 14, n. 4, pp. 318-326, 2018.

[7] FERREIRA, F.G., "Estudo da Delaminação em Compósitos de Epóxido Reforçado com Borracha e Fibras Naturais", Dissertação de Mestrado, Instituto Superior de Engenharia do Porto (ISEP), 2015.

[8] ALVES, M.C.S., GONÇALVES, M.T.T., VARASQUIM, F.M.F.D.A., et al., "Análise da influência da velocidade de corte, da granulometria da lixa e da pressão específica de corte no processo de lixamento", In: VI Congresso Nacional de Engenharia Mecânica - CONEM 2010, pp. 1-11, Campina Grande, 2010.

[9] OLIVEIRA, C.A.M., VERONEZE, T., ARAÚJO, M.S., et al., "Teste de usinabilidade de compósitos de epóxi e alumínio em CNC correlacionando parâmetros de corte a rugosidade superficial média ra e a defeitos por meio de superfície de resposta”, In: VI Congresso Nacional de Engenharia Mecânica - CONEM 2010, pp. 1-10, Campina Grande, 2010.

[10] LACHAUD, F., PIQUET, R., COLLOMBET, F., et al., "Drilling of composite structures", Composite Structures, v. 52, pp. 511-516, 2001.

[11] MELENTIEV, R., PRIARONE, P.C., ROBIGLIO, et al., "Effects of Tool Geometry and Process Parameters on Delamination in CFRP Drilling: An Overview”, Procedia CIRP, v. 45, pp. 31-34, 2016.

[12] VARASQUIM, F.M.F.D.A., "Efeitos da granulometria, do desgaste e do material abrasivo no lixamento plano de madeiras", Tese de Doutorado, Universidade Estadual Paulista (UNESP), Guaratinguetá, SP, Brasil 2014.

[13] RITTER, E.F., FARIAS, J.B.S., "Estudo do comportamento da força de corte e da rugosidade no torneamento de compósito de polipropileno com casca de arroz", In: VI Congresso Nacional de Engenharia Mecânica - CONEM 2010, pp. 1-9, Campina Grande, 2010.

[14] XU, J., LI, C., MI, S., et al., "Study of drilling-induced defects for CFRP composites using new criteria", Composite Structures, v. 201, pp. 1076-1087, 2018.

[15] SANKAR, B.R., UMAMAHESWARRAO, P., REDDY, A.V.A., et al., "Perfuração de Laminados Compostos - Uma Revisão", Revista de Pesquisa de Engenharia Básica e Aplicada, v. 1, n. 3, pp. 19-24, 2014.

[16] EBERHARDT, G.G., BOEHS, L., SALMORIA, G.V., “Avaliação da qualidade dos furos na usinagem de compósitos à base de resina epóxi com e sem carga de pó-de-ferro" In: VI Congresso Nacional de Engenharia Mecânica - CONEM 2010, pp. 1-10, Campina Grande, Brasil, 2010.

[17] EL-SONBATY, I., KHASHABA, U.A., MACHALY, T., "Factors affecting the machinability of GFR/epoxy composites", Composite Structures, v. 63, pp. 329-338, 2004.

[18] CAPELLO, E., "Workpiece Damping and its Effects on Delamination Damage in Drilling thin Composite Laminates", Journal of Materials Processing Technology, v. 148, pp. 186-195, 2004. 


\section{ORCID}

Jussara Smidt Porto

Clarissa Coussirat Angrizani

Eliana Paula Calegari

Sandro Campos Amico

Lauren da Cunha Duarte https://orcid.org/0000-0002-3843-4934

https://orcid.org/0000-0002-6216-9712

https://orcid.org/0000-0001-5568-4620

https://orcid.org/0000-0003-4873-2238

https://orcid.org/0000-0001-5690-0794 